\title{
Tear Film and Ocular Surface Surfactants
}

\author{
Lars Bräuer and Friedrich P. Paulsen*
}

Department of Anatomy and Cell Biology, Martin Luther University of Halle-Wittenberg, Halle/Saale, Germany

\begin{abstract}
The hydrophobic surfactant proteins B (SP-B) and C (SP-C) are tightly bound to phospholipids. These proteins play important roles in maintaining the surface tension-lowering properties of pulmonary surfactant. Surfactant protein $\mathrm{A}$ (SP-A) and D (SP-D) are extremely hydrophilic and are thought to have a role in recycling surfactant and especially in improving host defense in the lung. Moreover, SP-A supports the hydrophobic surfactant proteins during surfactant subtype assembly and inhibits secretion of lamellar bodies into the alveolar space. During recent years surfactant proteins have also been detected at locations outside the lung such as the lacrimal apparatus. In this review, the latest information regarding SP function and regulation in the human lacrimal system, the tear film and the ocular surface is summarized with regard to mucous epithelial integrity, rheological and antimicrobial properties of the tear film, tear outflow, certain disease states and possible therapeutic perspectives.
\end{abstract}

Keywords: Surfactant proteins, ocular surface, tear film, lacrimal apparatus.

\section{INTRODUCTION}

Each year worldwide 55 million ocular injuries occur (WHO-Program for the prevention of blindness). Ocular trauma and corneal ulcerations due to infection are the most significant causes of corneal blindness yearly leading to 1.6 million new instances of bilateral blindness, 2.3 million instances of serious limitation in visual acuity, and 19 million instances of unilateral blindness. In Germany, approximately 30 million people wear glasses or contact lenses. In the USA, the number approaches 120 million. In 1995, the number of radial keratotomies (RK) reached 250,000 in the USA (National Eye Institute). Meanwhile, RK has been almost completely superseded by LASIK (laser assisted in situ keratomelieusis) (1.55 million operations in the USA in the year 2000). These numbers have increased appreciably over the last seven years. The laser market has a yearly growth rate of $10-25 \%$. Although LASIK is a great deal safer and associated with fewer complications than RK and photoreactive keratoectomy, standardized numbers on the occurrence of LASIK related complications have not yet become available. To date, the only relevant publications have been based on small case numbers at individual centers.

Due to the difficulties involved in treating corneal blindness once it has developed, it is, from a medical point of view, well worth the effort to search for therapeutic strategies that could improve healing early and effectively, reduce infections and diminish corneal scarring in order to reduce the number of instances of persistent corneal blindness.

In ophthalmological practice, bacterial keratitis and conjunctivitis are among the most frequently seen problems. They represent an important component of numerous infections of the eye, particularly in patients after penetrating

*Address correspondence to this author at the Department of Anatomy and Cell Biology, Martin Luther University Halle-Wittenberg, Faculty of Medicine, Grosse Steinstr. 52, D-06097 Halle (Saale), Germany; Tel: +49 345 5571707; Fax: +49 345 5571700;

E-mail: friedrich.paulsen@medizin.uni-halle.de corneal injury, after lengthy periods of contact lens wear, after refractive corneal surgery or under immune suppression therapy [1-4]. The most frequent causal agents are the gram positive pathogen Staphylococcus aureus and the gram negative bacteria Pseudomonas aeruginosa [5, 6], but also viruses, e.g. the Herpes simplex virus, can instigate keratitis. Bacterial by-products and toxins as well as the host's inflammatory reaction often bring about extensive tissue damage with persistent scarring or even loss of sight [1].

It has long been known that tear fluid contains various anti-bacterially active substances. These substances are synthesized by various cells found in the lacrimal glands, the accessory lacrimal glands, the conjunctiva and the cornea. Of these antimicrobial substances, lysozyme [7], mainly effective against gram positive bacteria, has been most extensively described and studied. Further substances include the enzyme $\beta$-Lysin, which destroys bacterial cell membranes working synergistically with lysozyme [8], the iron-binding protein Lactoferrin, which inhibits growth of Bacillus subtilis, Staphylococcus aureus, Staphylococcus epidermidis and Pseudomonas aeruginosa $[9,10]$, as well as complement factors of the alternate pathway, which are activated directly by microbial products, e.g. endotoxins [11]. In the past few years, the research group surrounding Bernhard Redl has been able to better characterize the protein lipocalin present in the lacrimal fluid and has recently demonstrated that tearspecific lipocalin is bacteriostatic to Eschericha coli and various fungi via iron deprivation [12]. Recent research has further shown that lacrimal fluid contains secretory phospholipase $A_{2}$, an enzyme which, along with lysozyme and $B-$ lysin is particularly effective against gram-positive bacteria $[13,14]$.

A further mechanism of defence is represented by antimicrobial peptides. It is assumed that some of these peptides are able to kill microorganisms directly via formation of pores. For the remainder of these peptides the mechanism of activity has not yet been fully elucidated. The bestcharacterized group of antimicrobial peptides are the human 
defensins that can be subdivided into two groups, $\alpha$ defensins and $\beta$-defensins. Further antimicrobial peptides that have been described on the ocular surface include BPI (bactericidal permeability-increasing protein), CAP37 (heparin-binding protein), LL37 (human cationic antimicrobial protein/hCAP-18), LEAP1 (liver expressed antimicrobial peptide 1 or heptcidin) and LEAP 2 and angiogenin. A current review of antimicrobial pepitides at the ocular surface has been presented by McDermott [15].

\section{SURFACTANT PROTEINS}

The surfactant-associated proteins A and D (SP-A and SP-D) have been extensively described in research related to the lung. Immunological functions in both the non-specific and specific immune defence systems have been ascribed to them. SP-A and SP-D are representatives of the collectinfamily of the C-type, among with numerous other molecules of known immunological function may be counted.

According to the current understanding of the mechanism of C-type collectins, exposed microbiological carbohydrates (on the surface of diverse microorganisms) bind to a carbohydrate recognition domain inherent to the proteins. In this manner, opsonisation and acceleration of the defence reaction to the microorganism is achieved.

$\mathrm{SP}-\mathrm{A}$ is a $28-36 \mathrm{kDa}$ soluble protein first recognized in type II pneumocytes of the pulmonary epithelium and is expressed by these cells. SP-A isolated from broncheoalveolar lavage specimens is mainly present in the form of surfactantlipid-aggregates. Furthermore, the presence of SP-A augments the reduction in surface tension induced by SP-B in pulmonary alveoli. Nonetheless, deletion of the SP-A gene in mice does not lead to a decline in lung stability, albeit the protein inhibition of surfactant reveals an important functional relevance of SP-A [16]. SP-A bind to type II pneumocytes and to immune cells as well as to some extent to macrophages [17]. Beyond this, it has been demonstrated that SP-A deficient mice exhibit a weakened defence to various pulmonary pathogens [18].

SP-D is a $43 \mathrm{kDa}$ protein synthesized not only by type II pneumocyte epithelium, but also by various cells of the respiratory tract and mucous cells of the stomach. It is characterized by a very high structural similarity and, correspondingly, homology to SP-A and other mammalian specific lectins [19]. The lectin domain of SP-D, mediated by calcium ions, bind to carbohydrates and lipids, playing a role in the innate immune defence particularly against bacterial, viral and fungiform pathogens. It interacts directly with a number of microorganisms such as influenza virus A [20], Pseudomonas aeruginosa and Escherichia coli [21, 22]. In addition, its important role in lipid homeostasis of the lung could be demonstrated through the selective deletion of SP-D in mice [23]. SP-D deficient mice develop alveolar lipidosis, which is accompanied by the activation of macrophages and an increased activation of metalloproteinases [24]. Beyond this, the SP-D deficient mice develop emphysema-like pathological changes reflecting the critical role of the surfactant proteins in the regulation of pulmonary inflammation.

The first description of proteins in organic extracts of extracellular surfactant and lamellar bodies was presented by Phizackerley et al. in 1979 [25]. The characterization and purification of these proteins proved quite difficult due to their high hydrophobicity and low molecular weights. Finally, it could be demonstrated that pulmonary surfactant contains at least two different small molecular weight hydrophobic proteins, known as SP-B and SP-C [26, 27]. Using non-reducing preparation-conditions the molecular weights of SP-B by means of SDS-PAGE have been estimated at approximately $15-18 \mathrm{kDa}$, whereas under reducing conditions a suitably separable product of approximately $7 \mathrm{kDa}$ was obtained [28, 29]. SP-B, post-translationally produced from a preform is also able to form oligomeres of various sizes via disulfide bridges [29]. SP-C, utilising 33-35 amino acids, is one of the smallest and at the same time most hydrophobic proteins known, with a molecular weight of 4-6 $\mathrm{kDa}[30,31]$. Its primary translation product consists of 191 amino acids. As does SP-B, SP-C also undergoes extensive post-translational modification, for example, glycosylation, acylation or esterification with fatty acids [32-35]. In contrast to the sugar binding collectin-like SP-A and SP-D, SP$\mathrm{B}$ and SP-C are decisive in the formation and stability of surface active layers (membranes) and beyond this are a prerequisite for the absorption of phospholipids at the air-fluid boundary [36, 37]. Due to their hydrophobic properties, SP$\mathrm{B}$ and SP-C are of great pathophysiological relevance in acute respiratory distress syndrome (ARDS) as diverse plasma proteins inhibit the formation of pulmonary surfactants and thus decrease alveolar surface tension [38]. In this context it has been reported that the deletion of SP-B in newborn rabbits leads to serious disturbance of the affected surfactant and injury to the alveolar surface of therewith engendered respiratory stress in the rabbit [39]. The function of SP-C is comparable to SP-B in that it is characterized by its direct influence and interaction with biological and phase interfaces; it namely reduces surface tension and increases the ability to absorb the surfactant, like an anchor mediating between the phopholipid layer and the aqueous phase.

\section{SURFACTANT PROTEINS OF THE TEAR FILM, OCULAR SURFACE AND LACRIMAL APPARATUS}

The Meibomian glands of the eyelids are responsible for the production of the superficial lipid components of the tear film which counteract evaporative tendencies of the deeper tear film layers directly adjacent to and protecting the ocular surface [40]. The lacrimal glands, along with the accessory glands of the lids, express the watery components of the tear film. These play a role not only in moistening of the ocular surface, but also in defending against potentially pathogenic microorganisms [13]. The mucous components of the tear film consist for the most part of secretory mucins produced in conjunctival goblet cells, the lacrimal and accessory lacrimal glands, as well as of membrane bound mucins synthesized by conjunctival and corneal epithelial cells [41-45]. Membrane bound mucins may be split from the epithelial surface via a process known as shedding, and thus may also enter the aqueous component of the tear film [44, 45].

For a long time it has been supposed that superficially active substances, similar to the surfactant system of the lung, are of importance not only in tear film but also in the auditory tube and on the skin [46]. Various studies have documented the presence of surfactant-associated proteins A, $\mathrm{B}$ and $\mathrm{D}$ in the auditory tube [47] and of SP-A, B, C and D in the skin [48]. The presence of SP-D has already been described in tear film and lacrimal glands [49-51]. Ni et al. 
[52] was able to show that beyond this, SP-D is present in the cornea of mice and has protective effects against keratitis caused by $P$. aeruginosa. Although Dobbie et al. [53] had already presented immunohistochemical evidence of the presence of SP-A in the human lacrimal gland, these findings were pushed into the background by Stahlmann et al. [50] and $\mathrm{Ni}$ et al. [52] as the latter authors could not demonstrate SP-A in tear fluid of mice and their findings were taken to be conclusive for humans as well. Our group has now been able to show that not only SP-D, but also the surfactantassociated protein A, along with SP-B and SP-C is present at the ocular surface, in the lacrimal apparatus and in tears [54, 55]. Thereby, all of the surfactant-associated proteins (SP's) proved to be detectable at the mRNA and protein levels throughout the lacrimal apparatus and on the ocular surface in all tissues studied (lacrimal glands, conjunctiva, cornea, lacrimal ducts) as well as in tear fluid itself. Interestingly, SP-A and SP-C in tear fluid, and SP-C in all examined tissues, show an expression pattern differing from that of lung surfactant proteins. This is probably due to tissue specific post-translational or post-transcriptional modifications of the proteins and may lead to differences in the spectrum of activity of the surfactant proteins. SP-A, -B, -C and -D are found in the acinar cells of the lacrimal gland and the accessory tear ducts, in the conjunctival epithelial cells and in columnar epithelial cells (particularly apically) as well as in serous portions of seromucous glands in the tear ducts and the accessory tear ducts. Goblet cells do not produce any of the four SP's. In contrast to tear fluid, the aqueous humor does not show the presence of SP's under physiological conditions [54]. In healthy corneal specimens, the two collectins SP-A and SP-D are only found as a thin film in the apical region of the superficial cells. SP-B and SP-C are immunohistochemically undetectable within and on the surface of the cornea [55]. In contrast, pathologically altered corneae show a completely different distribution pattern. In association with herpes keratitis and corneal ulceration (caused by $S$. aureus), SP-A and SP-D are found in the vicinity of the lesion sites as well as in invading immune cells; in the corneae of patients with keratoconus the entire epithelium and the endothelium react positively. Cultured corneal and conjunctival epithelial cell lines also produce SP-A and SP-D [54]. Stimulation of corneal and conjunctival epithelial cell lines $[56,57]$ with various cytokines and bacterial supernatants lead to an increase of both collectins. Thus, in addition to SP-D which has already been reported to be present in tear film $[49,50,52]$, there are also SP-A, SP-B and SP-C proteins in the lacrimal fluid and on the ocular surface.

\section{CONCLUSIONS}

Based on the present status of knowledge including that gleaned from animal experimental studies on SP-D [52, 58] it can be assumed that the collectins, SP-A and SP-D, are involved in pathological processes at the ocular surface and function here, as well as in the efferent tear ducts, in the service of non-specific natural immune defence and in the activation of the adaptive immune system. As a substance intrinsic to tears they protect the ocular surface in conjunction with immunoglobulin A (IgA), defensins and mucins against infection by $P$. aeruginosa, $S$. aureus and other pathogenic microbes $[15,52,59-62]$. In the efferent tear ducts they are also active in conjunction with $\mathrm{IgA}$, antimi- crobial peptides and mucins in preventing the formation of dacryocystitis [54, 55, 63-70].

In view of the fact that the hydrophobic surfactant proteins SP-B and SP-C have an expanding influence on the surface tension of the air-liquid interface on top of the alveolar lining layer, a similar effect could be discussed in relation to the tear film and the tear fluid at the human ocular surface and efferent tear ducts. In this context we provide a completed and modified scheme of the tear film which now contains the evidenced and investigated surfactant proteins with respect to their physicochemical properties and discussed putative functions in tears, the lacrimal apparatus and at the ocular surface (Fig. 1). This view demonstrates the small hydrophobic surfactant proteins $\mathrm{B}$ and $\mathrm{C}$ embedded into the lipid component of the tear film, orientated regarding to their amphiphilic character. Furthermore, the water-soluble and polymerizeable collectin-like surfactant proteins A and D are arranged within the aqueous component of the tear film along with the already known different secreted and shedded mucins. This hypothetical model supports possible functions of surfactant proteins with regard to severe pathologies of the ocular surface e.g. dry eye syndrome and bacterial or viral infections. Dysfunctions of the complex ocular surfactant system would probably lead to considerable visual impairment and disturbances of the immune defence system of the ocular surface and lacrimal apparatus. Hypothetically, absence of the small hydrophobic surfactant proteins B and $\mathrm{C}$ could result in alterations of tear film stability and as a consequence in interruption of the tear film itself leading to symptoms of dry eye syndrome such as for example dry spots. Disturbed production or lack of the immunologically important surfactant proteins A and D could lead to impairment of innate and adaptive immunity at the ocular surface and in the lacrimal system resulting in various bacterial and/or viral infections.

\section{PERSPECTIVES}

By means of the developement of a gene construct for all four surfactant proteins, which includes open reading frames for mature and preforms of the proteins, a prerequisite has been formed for the establishment of a system of expression via which all four SP's can be manufactured using recombinant methods. The thus manufactured recombinant SP's could serve in functional studies on questions pertaining to the ocular surface and the lacrimal system. Some recombinant SP's have already been manufactured (for a review see $[71,72])$. With the software programs and methods available today, it is possible to create a reliable model of the 3Dstructure of proteins and to identify the active sites by using comparative protein modelling or threading. Blocking or modification of putative active sites could alter the functionality of the proteins and lead to completely new proteins at a functional level. Up to now there is no information on the ocular surface and lacrimal system of surfactant-deficient mice, which are already available for all four SP's [23, 7375]. In studies on conditions of chronic infection of the ocular surface such as that found, for example, in dry eyes, it would be of interest to know whether individual SP formation is increased or decreased. An increase in surfactant formation over a lengthy period of time would very possibly have negative consequences for the body as a whole. In this context it has been demonstrated that SP-D exhibits proat- 


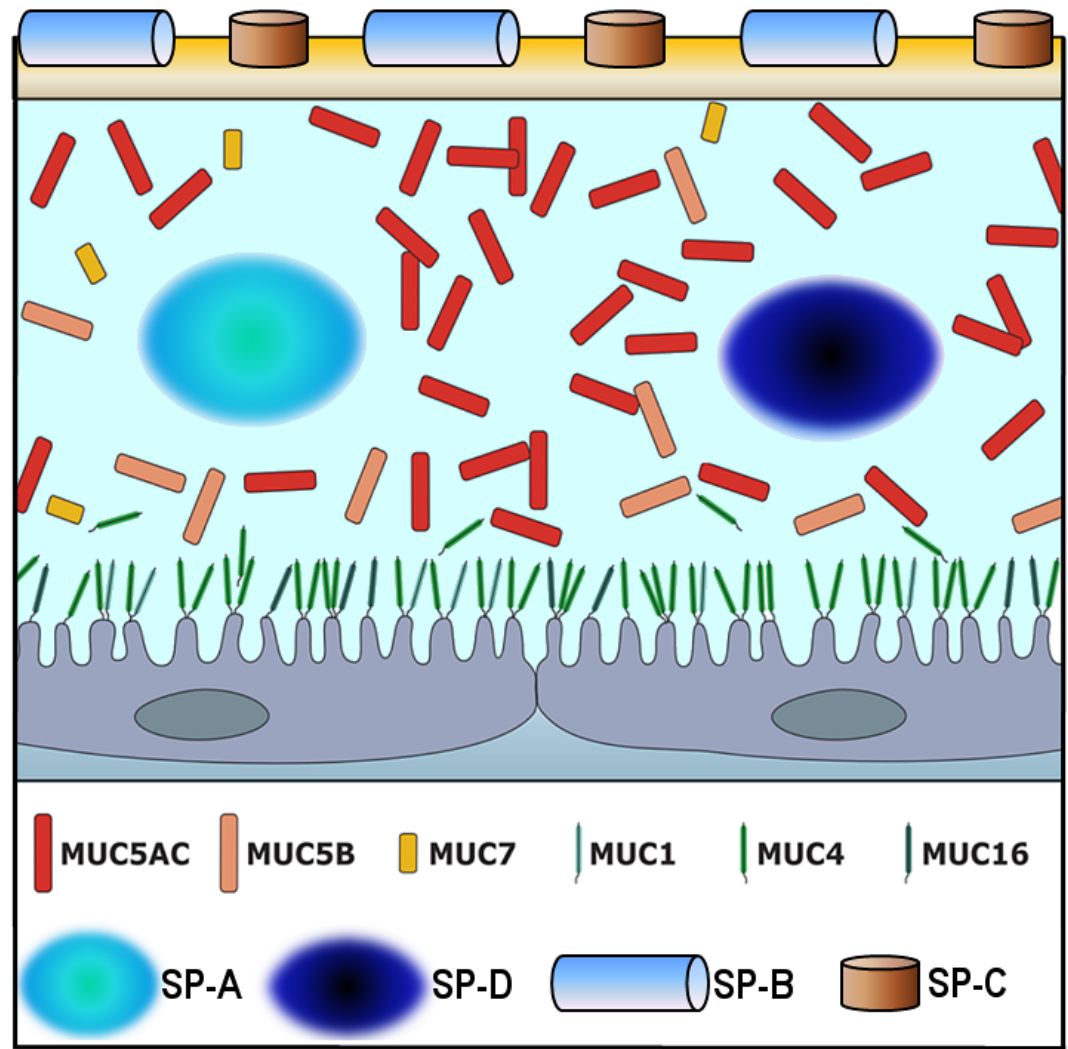

lipid

component

mucous

component

corneal

epithelium

Fig. (1). The figure demonstrates a modified and completed scheme of the present understanding of the tear film in accordance to that recently published by Paulsen (2006). It displays the arrangement of the water-soluble and putative immunologically important surfactant proteins $\mathrm{A}$ and $\mathrm{D}$ within the aqueous phase of the tear film. Furthermore, the small hydrophobic surfactant proteins B and C are illustrated. They are embedded into the lipid-phase of the tear film with respect to their physicochemical propteries. Moreover, most of the already known and still investigated mucins of the ocular surface and tear film are shown along with SP-A and SP-D.

herogenous activity in mice [76]. Studies on the surfactantprotein system of the ocular surface have just begun and lead us to expect interesting new discoveries in regard to future therapeutic perspectives.

\section{ACKNOWLEDGEMENT}

This work was supported by grants from the Deutsche Forschungsgemeinschaft (DFG) - program grants PA 738/91, PA 738/9-2 and PA 738/1-5, the BMBF - Wilhelm Roux Program, Halle, Germany - program grants FKZ 09/17, as well as Sicca Forschungsförderung of the Association of German Ophthalmologists

\section{LIST OF ABBREVIATIONS}

$\begin{array}{ll}\mathrm{SP} & =\text { surfactant protein } \\ \mathrm{WHO} & =\text { Word Health Organization } \\ \mathrm{RK} & =\text { radial keratotomy } \\ \text { LASIK } & =\text { laser assisted in situ keratomelieusis } \\ \text { CAP37 } & =\text { heparin-binding protein } \\ \text { LL37 } & =\text { human cationic antimicrobial protein } \\ \text { hCAP18 } & =\text { human cationic antimicrobial protein } \\ \text { LEAP1 } & =\text { liver expressed antimicrobial peptide } \\ \text { LEAP2 } & =1 / \text { heptcidin }\end{array}$

LEAP2 $=$ liver expressed antimicrobial peptide 2

$$
\begin{array}{ll}
\text { SDS-PAGE } & =\begin{array}{l}
\text { sodium dodecyl sulfate-polyacrylamide gel } \\
\text { electrophoresis }
\end{array} \\
\text { ARDS } & =\text { acute respiratory distress syndrome } \\
\text { mRNA } & =\text { messenger ribonucleic acid } \\
\text { IgA } & =\text { immunoglobulin A }
\end{array}
$$

\section{REFERENCES}

[1] Baum J. Infections of the eye. Clin Infect Dis 1995; 21: 479-88.

[2] Gritz DC, Whitcher JP. Topical issues in the treatment of bacterial keratitis. Int Ophthaomol Clin 1998; 38: 107-14.

[3] Brennan NA, Chantal Coles ML. Extended wear in perspective. Invest Ophthalmol Vis Sci 1997; 74: 609-23.

[4] Levartovsky S, Rosenwasser G, Goodman D. Bacterial keratitis following laser in situ keratomileusis. Ophthalmology 2001; 108: 321-5.

[5] Fleiszig SMJ, Efron N, Pier GB. Extended contact lens wear enhances Pseudomonas aeruginosa adherence to human conrneal epithelium. Invest Ophthalmol Vis Sci 1992; 33: 2908-16.

[6] O'Callaghan RJ, Cellegan MC, Moreau JM, et al. Specific roles of alpha-toxin and beta-toxin during Staphylococcus aureus corneal infection. Infect Immun 1997; 65: 1571-8.

[7] Fleming A. On a remarkable bacteriolytic element found in tissues and secretions. Proc R Soc B 1922; 93: 306-17.

[8] Pleyer U, Baatz H. Antibacterial protection of the ocular surface. Ophthalmologica 1997; 211 (Suppl 1): 2-8.

[9] Oram J, Reiter B. Inhibition of bacteria by lactoferrin and other iron-chelating agents. Biochim Biophys Acta 1979; 170: 351-3.

[10] Kijlstra A. The role of lactoferrin in the nonspecific immune response on the ocular surface. Regul Immunol 1990; 3: 193-7.

[11] Fearson D, Austen K. The alternative pathway of complement: A system for host resistance to microbial infection. N Engl J Med 1980; 303: 259-61. 
[12] Fluckinger M, Haas H, Merschak P, Glasgow BJ, Redl B. Human tear lipocalin exhigits antimicrobial activity by scavenging microbial siderophores. Antimicrob Agents Chem 2004; 48: 3367-72.

[13] Qu X-D, Lehrer RI. Secretory phospholipase $A_{2}$ is the principal bactericide for staphylococci and other gram-positive bacteria in human tears. Infect Immun 1998; 66: 2791-9.

[14] Girgis DO, Dajes JJ, O'Callaghan RJ. Phospholipase A2 activity in normal and Staphylococcus aureus-infected rabbit eyes. Invest Ophthalmol Vis Sci 2003; 44: 197-202.

[15] McDermott AM. Defensins and other antimicrobial peptides at the ocular surface. Ocul Surf 2004; 2: 229-47.

[16] Korfhagen TR, Bruno MD, Ross GF, et al. Altered surfactant function and structure in SP-A gene targeted mice. Proc Natl Acad Sci USA 1996; 93: 9594-9.

[17] van Iwaarden F, Welmers B, Verhoef J, Haagsman HP, van Golde LM. Pulmonary surfactant protein A enhances the host-defense mechanism of rat alveolar macrophages. Am J Respir Cell Mol Biol 1990; 2: 91-8.

[18] Levine AM, Kurak KE, Bruno MD, Stark JM, Whitsett JA, Korfhagen TR. Surfactant protein-A-deficient mice are susceptible to Pseudomonas aeruginosa infection. Am J Respir Cell Mol Biol 1998; 19: 700-8

[19] Crouch E, Wright JR. Surfactant proteins a and d and pulmonary host defense. Annu Rev Physiol 2001; 63,521-54.

[20] Hartshorn KL, Crouch E, White MR, et al. Pulmonary surfactant proteins $A$ and $D$ enhance neutrophil uptake of bacteria. Am J Physiol 1998; 274: L958-69.

[21] Sastry K, Ezekowitz RA. Collectins: pattern recognition molecules involved in first line host defense. Curr Opin Immunol 1993; 5: 5966.

[22] Ferguson JS, Voelker DR, McCormack FX, Schlesinger LS. Surfactant protein D binds to Mycobacterium tuberculosis bacilli and lipoarabinomannan via carbohydrate-lectin interactions resulting in reduced phagocytosis of the bacteria by macrophages. J Immunol 1999; 163: 312-21.

[23] Botas C, Poulain F, Akiyama J, et al. Altered surfactant homeostasis and alveolar type II cell morphology in mice lacking surfactant protein. D Proc Natl Acad Sci USA 1998; 95: 11869-74.

[24] Wert SE, Yoshida M, LeVine AM, et al. Increased metalloproteinase activity, oxidant production, and emphysema in surfactant protein D gene-inactivated mice. Proc Natl Acad Sci USA 2000; 23: 5972-7.

[25] Phizackerley PJ, Town MH, Newman GE. Hydrophobic proteins of lamellated osmiophilic bodies isolated from pig lung. Biochem J 1979; 183: 731-6.

[26] Yu SH, Chung W, Olafson RW, Harding PG, Possmayer F. Characterization of the small hydrophobic proteins associated with pulmonary surfactant. Biochim Biophys Acta 1987; 921: 437-48.

[27] Whitsett JA, Hull WM, Ohning B, Ross G, Weaver TE. Immunologic identification of a pulmonary surfactant-associated protein of molecular weight $=6000$ daltons. Pediatr Res 1986; 20: 744-49.

[28] Yu SH, Wallace D, Bhavnani B, Enhorning G, Harding PG, Possmayer F. Effect of reconstituted pulmonary surfactant containing the 6000-dalton hydrophobic protein on lung compliance of prematurely delivered rabbit fetuses. Pediatr Res 1988; 23: 23-30.

[29] Whitsett JA, Ohning BL, Ross G, et al. Hydrophobic surfactantassociated protein in whole lung surfactant and its importance for biophysical activity in lung surfactant extracts used for replacement therapy. Pediatr Res 1986; 20: 460-7.

[30] Possmayer F. A proposed nomenclature for pulmonary surfactantassociated proteins Am Rev Respir Dis 1988; 138: 990-8.

[31] Hawgood S, Shiffer K. Structures and properties of the surfactantassociated proteins Annu Rev Physiol 1991; 53: 375-394.

[32] Voorhout WF, Veenendaal T, Haagsman HP, et al. Intracellular processing of pulmonary surfactant protein $\mathrm{B}$ in an endosomal/lysosomal compartment. Am J Physiol 1992; 263: 479-86.

[33] Glasser SW, Korfhagen TR, Perme CM, Pilot-Matias TJ, Kister SE, Whitsett JA. Two SP-C genes encoding human pulmonary surfactant proteolipid. J Biol Chem 1988; 263: 10326-31.

[34] Jacobs KA, Phelps DS, Steinbrink R, et al. Isolation of cDNA clone encoding a high molecular weight precursor to a $6-\mathrm{kDa}$ pulmonary surfactant-associated protein. J Biol Chem 1987; 262: 9808-11.

[35] Curstedt $\mathrm{T}$, Johansson J, Barros-Soederling J, et al. Lowmolecular-mass surfactant protein type 1 . The primary structure of a hydrophobic 8-kDa polypeptide with eight half-cystine residues. Eur J Biochem 1988; 172: 521-5.

[36] Yu SH, Possmayer F. Role of bovine pulmonary surfactantassociated proteins in the surface-active property of phospholipid mixtures. Biochim Biophys Acta 1990; 1046: 233-41.

[37] Notter RH, Shapiro DL, Ohning B, Whitsett JA. Biophysical activity of synthetic phospholipids combined with purified lung surfactant 6000 dalton apoprotein. Chem Phys Lipids 1987; 44: 1-17.

[38] Spragg, RG, Gilliard, N, Richman, P. In: Robertson B, van Golde LMG Batenburg JJ, Eds. Pulmonary Surfactant: From molecular biology to clinical practice. Amsterdam, Elsevier. 1992; 685-703.

[39] Kobayashi T, Nitta K, Takahashi R, Kurashima K, Robertson B, Suzuki Y. Activity of pulmonary surfactant after blocking the associated proteins SP-A and SP-B. J Appl Physiol 1991; 71: 530-6.

[40] McCulley JP, Shine WE. Meibomian gland function and the tear lipid layer. Ocul Surf 2003; 1: 97-106.

[41] Gipson IK, Hori Y, Argueso P, et al. Character of ocular surface mucins and their alteration in dry eye disease. Ocul Surf 2004; 2: 131-48.

[42] Jumblatt MM, McKenzie RW, Steele PS, Emberts CG, Jumblatt JE. MUC7 expression in the human lacrimal gland and conjunctiva. Cornea $2003 ; 22: 41-5$.

[43] Paulsen F, Langer G, Hoffmann W, Berry M. Human lacrimal gland mucins. Cell Tissue Res 2004; 316: 167-77.

[44] Paulsen F. Cell and molecular biology of human lacrimal gland and nasolacrimal duct mucins. Int Rev Cytol 2006; 249: 229-79.

[45] Paulsen F, Berry M. Mucins and TFF peptides of the tear film and lacrimal apparatus. Prog Histochem Cytochem 2006; 41: 1-53.

[46] Ridsdale RA, Palaniyar N, Possmayer F, Harauz G. Formation of folds and vesicles by dipalmitoylphosphatidylcholine monolayers spread in excess. J Membr Biol 2001; 180: 21-32.

[47] Paananen R, Sormunen R, Glumoff V, van Eijk M, Hallman M. Surfactant proteins A and D in Eustachian tube epithelium. Am J Physiol Lung Cell Mol Physiol 2001; 281: 660-7.

[48] Mo YK, Kankavi O, Masci PP, et al. Surfactant protein expression in human skin: evidence and implications. J Invest Dermatol 2007; 127: 381-6.

[49] Madsen J, Kliem A, Tornoe I, Skjodt K, Koch C, Holmskov U. Localization of lung surfactant protein D on mucosal surfaces in human tissues. J Immunol 2000; 164: 5866-70.

[50] Stahlman MT, Gray ME, Hull WM, Whitsett JA. Immunolocalization of surfactant protein-D (SP-D) in human fetal, newborn, and adult tissues. J Histochem Cytochem 2002; 50: 651-60.

[51] Akiyama J, Hoffman A, Brown C, et al. Tissue distribution of surfactant proteins A and D in the mouse. J Histochem Cytochem 2002; 50: 993-6.

[52] Ni M, Evans DJ, Hawgood S, Anders EM, Sack RA, Fleiszig SM. Surfactant protein D is present in human tear fluid and the cornea and inhibits epithelial cell invasion by Pseudomonas aeruginosa. Infect Immun 2005; 73: 2147-56.

[53] Dobbie JW, Tasiaux N, Meijers P, et al. Lamellar bodies in synoviocytes, mesothelium and specific epithelia as possible site of auto-antigen in rheumatoid disease. Br J Rheumatol 1994; 33: 50819.

[54] Bräuer L, Kindler C, Jäger K, et al. Detection of surfactant proteins $\mathrm{A}$ and $\mathrm{D}$ in human tear fluid and the human lacrimal system. Invest Ophthalmol Vis Sci 2007; 48: 3945-53.

[55] Bräuer L, Börgermann J, Johl M, Pleyer U, Tsokos M, Paulsen F. Detection and localization of the hydrophobic surfactant proteins $\mathrm{B}$ and $\mathrm{C}$ in human tear fluid and the human lacrimal system. Curr Eye Res 2007; 32: 931-8.

[56] Araki-Sasaki K, Ohashi Y, Sasabe T, et al. An SV40-immortalized human corneal epithelial cell line and its characterization. Invest Ophthalmol Vis Sci $1995 ; 36: 614-21$.

[57] Diebold Y, Calonge M, Enriquez de Salamanca A, et al. Characterization of a spontaneously immortalized cell line (IOBA-NHC) from normal human conjunctiva. Invest Ophthalmol Vis Sci 2003 ; $44: 4263-74$.

[58] McCormick CC, Hobden JA, Balzli CL, et al. Surfactant protein D in Pseudomonas aeruginosa keratitis. Ocul Immunol Inflamm 2007; 15: 371-9.

[59] Masinick SA, Montgomery CP, Montgomery PC, Hazlett LD. Secretory IgA inhibits Pseudomonas aeruginosa binding to cornea and protects against keratitis. Invest Ophthalmol Vis Sci 1997; 38: 910-8. 
[60] McNamara NA,Van R, Tuchin OS, Fleiszig SM. Ocular surface Epithelia expression mRNA for human beta defensin-2. Exp Eye Res 1999; 69: 483-90.

[61] McNamara NA, Andika R, Kwong M, Sack RA, Fleiszig SM. Interaction of Pseudomonas aeruginosa with human tear fluid components. Curr Eye Res 2005; 30: 517-25.

[62] Kwong MSF, Evans DJ, Ni M, Cowell BA, Fleiszig SMJ. Human tear fluid protects against Pseudomonas aeruginosa keratitis in a murine experimental model. Infect Immun 2007; 75: 2325-32.

[63] Paulsen F, Thale A, Kohla G, et al. Functional anatomy of human duct epithelium. Anat Embryol 1998; 198: 1-12.

[64] Paulsen F, Pufe T, Schaudig U, et al. Detection of natural peptide antibiotics in human nasolacrimal ducts. Invest Ophthalmol Vis Sci 2001; 42: 2157-63.

[65] Paulsen F, Pufe T, Schaudig U, et al. Protection of human efferent tear ducts by antimicrobial peptides. Adv Exp Med Biol 2002; 506: 547-53.

[66] Paulsen F, Corfield A, Hinz M, et al. Characterization of mucins in human lacrimal sac and nasolacrimal duct. Invest Ophthalmol Vis Sci 2003; 44: 1807-13.

[67] Paulsen F, Corfield A, Hinz M, et al. Tränenabfluss - Bedeutung von Muzinen und TFF-Peptiden. Ophthalmologe 2004; 101: 19-24.

[68] Paulsen F, Varoga D, Steven P, Pufe T. In: Zierhut M, Stern ME, Sullivan DA, Eds. Immunology of Lacrimal Gland and Tear Film. London, Taylor \& Francis. 2005; 97-104.
[69] Paulsen F. In: Weber R, Keerl R, Schaefer SD, Della Rocca RC, Eds. Atlas of Lacrimal Surgery. Berlin, Heidelberg, New York, Springer. 2007; 1-13.

[70] Paulsen F. Functional anatomy and immunological interactions of ocular surface and adnexa. Dev Ophthalmol 2008; 41: 21-35.

[71] Pfister RH, Soll RF. New synthetic surfactants: the next generation? Biol Neonate 2005; 87: 338-44.

[72] Sorensen GL, Husby S, Holmskov U. Surfactant protein A and surfactant protein D variation in pulmonary disease. Immunobiology $2007 ; 212: 381-416$

[73] Akinbi HT, Breslin JS, Ikegami M, et al. Rescue of SP-B knockout mice with a truncated SP-B proprotein. J Biol Chem 1997; 272: 9640-7.

[74] Li G, Siddiqui J, Hendry M, et al. Surfactant protein-A-deficient mice display an exaggerated early inflammatory reponse to a $B$ resistant strain of influenza A virus. Am J Respir Cell Mol Biol 2002; 26: 277-82.

[75] Glasser SW, Burhans MS, Korfhagen TR, et al. Altered stability of pulmonary surfactant in SP-C-deficient mice. Proc Nat Acad Sci 2001; 98: 6366-71.

[76] Sorensen GL, Madsen J, Kejling K, et al. Surfactant protein D is proatherogenic in mice. Am J physiol Hear Circ Physiol 2006; 290 H2286-94.

Received: June 06, 2008

(C) Bräuer and Paulsen; Licensee Bentham Open.

This is an open access article licensed under the terms of the Creative Commons Attribution Non-Commercial License (http://creativecommons.org/licenses/by-nc/3.0/) which permits unrestricted, non-commercial use, distribution and reproduction in any medium, provided the work is properly cited. 